\title{
DESIGN OF CENTER PIVOT IRRIGATION SYSTEM BASED ON SIMULATION MODEL TECHNIQUE
}

\section{Yousria Atef*}

Yasser E. Arafa*

\author{
Abdel-Ghany M. El-Gindy*
}

Essam A. Wassif**

\section{ABSTRACT}

Centre pivot irrigation system is a promising and precise system, for increasing the utilization efficiency of unit water. Hence, A CPIM simulation model has been developed and validated, however, A CPIM model is based on crop type, weather data, and soil characteristics. The model comprises five sub-models for: (a) main sub-model; (b) data entry sub-model; (c) weather sub-model; (d) irrigation sub-model; and (e) results sub-model. The most important simulation outputs of the CPIM model include nozzle flow rate $\left(\mathrm{m}^{3} / \mathrm{h}\right)$, application rate $(\mathrm{mm} / \mathrm{h})$, and throw diameter $(m)$. These outputs (outputs of 9 scenarios) were compared with observed/manufactured data for the calibration and validation of the model. Results of this comparison show that differences in model accuracy owing to different variables affecting the design and management of the center pivot were not significant. The relationships between the observed/manufactured and simulated results have a good correlation with high value of coefficient of determination and the best models are as follows:

1- Nozzle flow rate $\left(\mathrm{m}^{3} / \mathrm{h}\right)$ was in scenario 5 with $\mathrm{R}^{2}=0.967$ and explained by an exponential model: $\mathrm{Q}$ SIM $=0.1067 \mathrm{e}^{4.1131\left(\mathrm{Q}_{\mathrm{obs}}\right)}$.

2- Application rate $(\mathrm{mm} / \mathrm{h})$ was in all scenarios with a very high $\mathrm{R}^{2}$ and explained by a linear model.

3- Throw diameter (m) was in scenario 1 with $\mathrm{R}^{2}=0.942$ and explained by a power model: Dw SIM $=3.9064(\mathrm{Dw} \text { MFD })^{0.4361}$.

Keywords: Simulation; Model; Validation; Verification; Center pivot.

\section{INTRODUCTION}

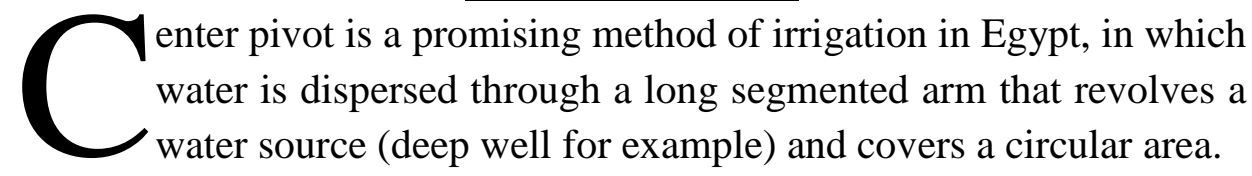

\footnotetext{
* Agric. Eng. Dept., Fac. of Agric., Ain Shams Univ.

** Agric. Eng. Research Institute, ARC.
} 
A wide diffusion of the center pivot irrigation systems (Faci et al., 2001; Summers and Putnam, 2008) is due to two reasons: (I) automation is built into the center pivot device allowing for irrigation with minimal labor input; and (II) center pivot systems can be one of the most efficient and uniform methods of applying irrigation water. Currently, an objective of irrigation planners is to obtain a high level of irrigation management as general and center pivot irrigation management in specific.

Generally, simulation modeling techniques remains a valuable tool to address a variety of engineering problems (such as irrigation management), at the design, planning, and operations levels (Chung, 2003). Accordingly, the application of simulation models in irrigation water management reduces water and energy consumption which, leads to increase the efficiency of utilization of these resources (Montero et al., 2001). In practical, there are many simulation models that have proved a great success in the design and management of pressurized irrigation systems such as: the SpacePro model (Cape, 1998) for the purpose of selecting nozzle size and spacing for a given application; the SIRIAS model for sprinkler droplet simulation (Carrion et al., 2001); the TRAVGUN model for sprinkler application depth Smith et al. (2008).

Attempts to use simulation models in center pivot irrigation systems have been started the 1960s. Bittinger and Logenbaugh (1962) have proposed a model that simulates the precipitation under center pivots with the objective of defining the optimal sprinkler spacing in order to obtain uniform water distribution. Heermann and Hein (1968) continued this line of research by taking into account the overlapping effect of neighboring sprinklers, and introduced the uniformity coefficient that bears their name. In 1993, Evans et al. have developed the center pivot irrigation model software for water and/or water-nitrate distribution analyses from center pivots. Bremond and Molle (1995) developed a model for the simulation of water application under center pivots, focusing on irrigation uniformity. A sophisticated software package for center pivot evaluation and design (CPED) was introduced by Heermann and Stahl in 2004. 
The aim of this study was to open a new era of simulation model technique in design irrigation system in addition to its uses in managing on farm irrigation water.

\section{MATERIALS AND METHODS}

\section{Model conceptualization of CPIM}

The appropriate development of a simulation model begins with understanding and interpretation of the real system through one of the methods of system analysis. Thus the waterfall model is used in the model building which gives the possibility to programmers to follow phases of development of the program in a certain order. Figure (1) shows the general overview of sequential process used in the CPIM development.

\section{CPIM model development and description:}

The database contains information such as station information, weather information, and crop water data information. Consequently, the mathematical model of CPIM consists of five submodels was developed. A detailed description of the submodels is in the following subsection:

\subsection{Main submodel:}

CPIM main submodel is the way to interact with a computer using pictures and other visual elements displayed on a computer screen. This submodel directs the running of the model by offering the user ability to select subsequent submodels and load the data files. It is the main entry point as well as the highest level of the program.

\subsection{Data entry submodel:}

This submodel controls the optimization procedure by performing the required calculations related to the simulation constraints in order to run the CPIM simulation model. This enables the user to enter and edit the basic project data to simulate one or more operating scenarios. The basic project input data include:

The area dimensions; Type of water source; Available discharge of water source; Reference evapotranspiration (ETo) (whether entered manually by the user or retrieved from the database incorporated in the program for three cities); Wind speed; Soil type characteristics retrieved from the database; and Crop coefficient and root zone depth for each crop retrieved from the database. 


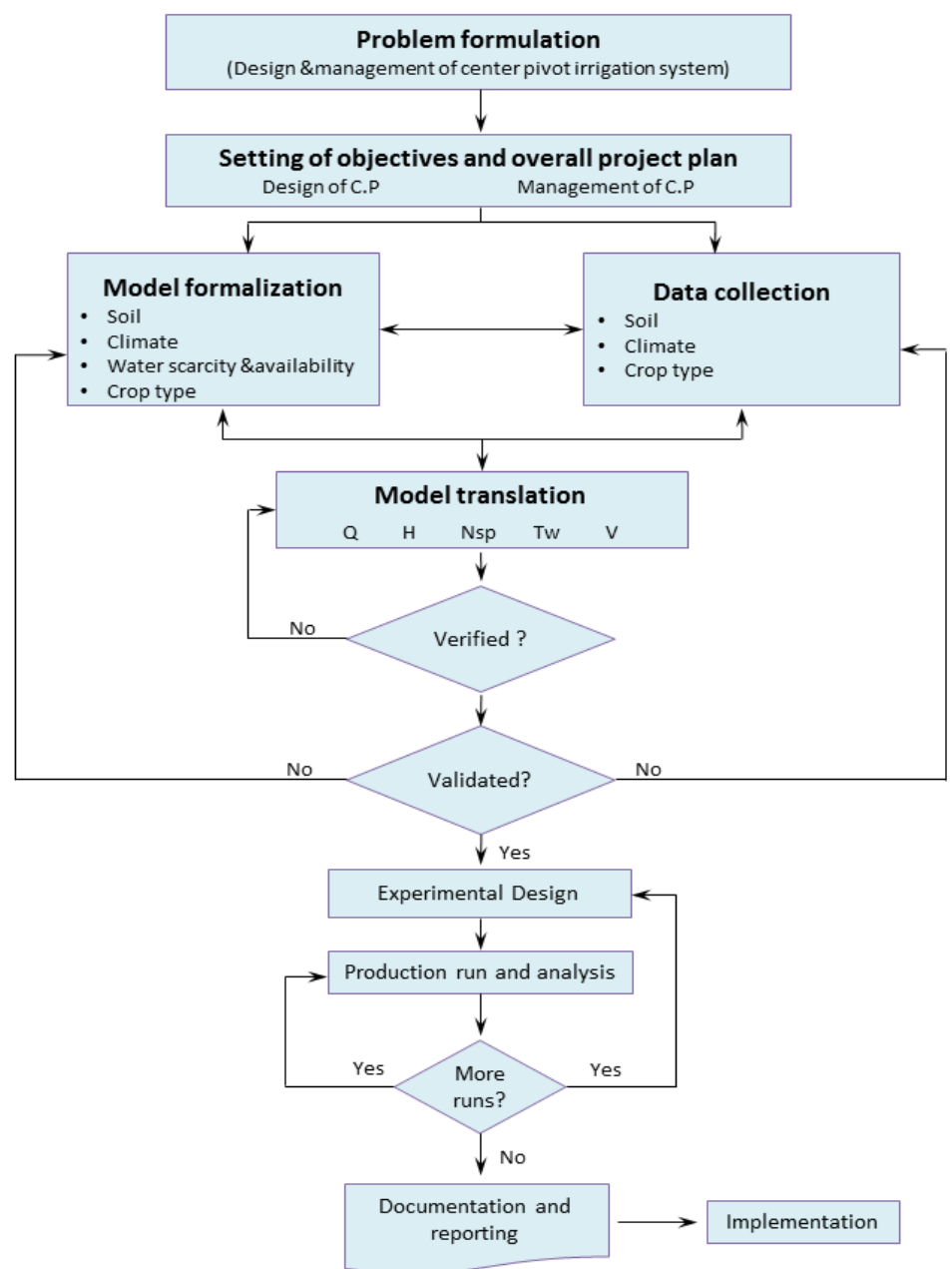

Fig. (1): General overview of sequential process used in the CPIM development.

\subsection{Weather submodel:}

The weather submodel calculates the monthly averages of evapotranspiration from the average five years daily data (2006-2010) retrieved from Central Laboratory for Agricultural Climate (CLAC). The monthly mean data of evapotranspiration for three stations located in $\mathrm{Al}$ Qalyubiyah, Menia, and Ismailia that used in the simulation model.

\subsection{Irrigation submodel:}

In this submodel, all the calculation related to crop water requirements, irrigation requirements, and center pivot irrigation system design are described. 
I. Center pivot system capacity $\left(\mathrm{Q}_{\mathrm{s}}, \mathrm{m}^{3} / \mathrm{h}\right)$ :

Center pivot system capacity design followed the methodology recommended by (Markley and Allen, 2007) as follows:

$$
\mathbf{Q}_{\mathbf{s}}=\mathbf{K} \times \mathbf{A} \times \mathbf{I}_{\mathbf{a}} / \mathbf{T}_{\mathbf{i}} \times \mathbf{T}
$$

Where: $\mathrm{K}$ is conversion factor $=0.001 ; \mathrm{A}$ is total irrigated area, $\mathrm{m}^{2} ; \mathrm{I}_{\mathrm{a}}$ is the irrigation requirement, $\mathrm{mm} ; \mathrm{T}_{\mathrm{i}}$ is the irrigation intervals and $\mathrm{T}$ is operating time, h/day.

II. Center pivot hydraulics analysis:

Simulation of hydraulic system includes determination of friction losses $(\mathrm{H} f, \mathrm{~m})$ along the sprinkler line, sprinklers operating pressure head $\left(\mathrm{H}_{\mathrm{sp}}\right.$, $\mathrm{m})$, nozzle size $\left(\mathrm{d}_{\mathrm{sp}}, \mathrm{mm}\right)$, nozzle discharge $\left(\mathrm{Q}_{\mathrm{sp}}, \mathrm{m}^{3} / \mathrm{h}\right)$ and Sprinkler throw diameter $\left(D_{w}, m\right)$. The hydraulic characteristics design followed the approaches proposed by (Keller and Bliesner, 1990; Merkley and Allen, 2007 and Al Ghobari, 2004) as the following equations:

- Friction head losses, $m$

$$
\mathrm{H}_{f}=1.22 \times 10^{12} \times f \times(\mathrm{R} / 100) \times\left(\mathrm{Q}_{S} / \mathrm{C}\right)^{1.852} \times \mathrm{D}^{-4.87}
$$

Where: $\mathrm{H}_{\mathrm{e}}$ is Pressure head required in the end of the sprinkler line, $\mathrm{m}$; $\Delta \mathrm{H}_{\mathrm{z}}$ is Height difference between pivot and the end of lateral, $\mathrm{m} ; \mathrm{H}_{\mathrm{rg}}$ is Head losses in pressure regulator, $\mathrm{m}$; $\mathrm{Hr}$ is Height of Sprinkler, $\mathrm{m}$.

- Sprinklers operating pressure head, $\mathrm{m}$

$$
\begin{aligned}
& H_{s p}=H_{f}\left(1-1.875\left(X-\left(2 X^{2} / 3\right)+\left(X^{5} / 5\right)\right)+H_{e}\right. \\
& X=r_{s p} / R
\end{aligned}
$$

- Nozzle size, $\mathrm{mm}$

$$
d_{\text {sp }}=30.46 \times\left(Q_{\text {sp }} / P_{\text {sp }}\right)^{1 / 2}
$$

- Nozzle discharge, $\mathrm{m} 3 / \mathrm{h}$

$$
\mathbf{Q}_{\mathrm{sp}}=\left(2 \mathbf{r}_{\mathrm{sp}} \times \mathbf{S}_{\mathrm{s}} \times \mathbf{Q}_{\mathrm{s}}\right) / \mathbf{R}^{2}
$$

- Sprinkler throw diameter, $\mathrm{m}$

$$
D_{w}=\mathbf{2 . 5 9}+0.56 d_{s p}+0.023 P_{s p}
$$

Where: Psp is sprinkler operating pressure in $\mathrm{kPa}$

III. Sprinkler application rate $(\mathrm{Ra}, \mathrm{mm} / \mathrm{h})$ :

The application rate of sprinkler, as described in the following equation, depends on distance to sprinkler at lateral $\left(\mathrm{r}_{\mathrm{sp}}, \mathrm{m}\right)$, system capacity $\left(\mathrm{Q}_{\mathrm{s}}\right.$, $\left.\mathrm{m}^{3} / \mathrm{h}\right)$, radius of center pivot $(\mathrm{R}, \mathrm{m})$ and throw diameter of sprinkler $\left(D_{\mathrm{w}}\right.$, $\mathrm{m})$.

$\mathbf{R}_{\mathrm{a}}=\left(2 \times 1000 \times \mathbf{r}_{\mathrm{sp}} \times \mathbf{Q}_{\mathrm{s}}\right) /\left(\mathbf{R}^{2} \times \mathbf{D}_{\mathrm{w}}\right)$ 


\subsection{Result submodel:}

One of the most important objectives of CPIM program was to create good output submodel that allows users generating and handling clear outputs easily. Reports of the output can be printed or saved in spreadsheets such as Microsoft Excel according to users' specific needs.

\section{Computer programming:}

The software code was developed using the C\# (programming language). (C\#) is an object-oriented programming language that is based on $\mathrm{C}++$ with elements from Visual Basic and Java.

\section{Model verification and validation:}

A field experiment on a single span from center pivot was used in this research for validation of the CPIM model. The center pivot system used in the experiment was configured with a span length of $56.7 \mathrm{~m}$ with flow rate of $4.2 \mathrm{~m}^{3} / \mathrm{h}$. Sprinklers were manufactured by Nelson Irrigation Corporation with pressure regulators of 1.03 bars. The distance from the sprinkler to the ground surface was $1.8 \mathrm{~m}$. Sprinklers throw diameter were varied in a range of 14 to $16 \mathrm{~m}$ from the beginning at the center pivot to the end of the center pivot radial line. Nozzle flow rate was determined for each nozzle along the radial line of the center pivot by using the following steps:

1. Measuring the sprinkler flow rate for three times with a pail and stop watch;

2. Averaging the flow rate.

While, the application rate $(\mathrm{mm} / \mathrm{h})$ and throw diameter $(\mathrm{m})$ data of sprinklers were downloaded from the official web site of center pivot provider for the same center pivot model used in the experiment (Nelson Irrigation Corporation). The capability of the CPIM model to simulate the center pivot irrigation processes with an acceptable level of accuracy had been evaluated by comparing its output of three parameters with 9 scenarios with field and manufactured data. The analyzed output variables include: (1) Nozzle flow rate $\left(\mathrm{m}^{3} / \mathrm{h}\right)$, (2) application rate $(\mathrm{mm} / \mathrm{h})$, and (3) throw diameter $(\mathrm{m})$. All scenarios have two types of boundary conditions. Firstly, are related to soil-plant-water relationship, while secondly, are related to center pivot irrigation management. Data 
of boundary conditions and limitations of the different scenarios of the validation case studies are shown in Table (1).

\section{Statistical analysis:}

To achieve the objectives of the research, hypothesis testing was performed through the use of statistical analysis. Descriptive statistics, tests of normality, and test of homogeneity of variances were initially used for analyzing the data using IBM SPSS Statistics version 20.0. An analysis of variance between groups (ANOVA) for both simulated and observed/manufactured data was performed. Nozzle flow rate $(\mathrm{m} 3 / \mathrm{h})$, application rate $(\mathrm{mm} / \mathrm{h})$, and throw diameter $(\mathrm{m})$ were included in the statistical analysis and tested for statistically significant differences at 5\% confidence level (Razali and Wah, 2011; Doane and Seward, 2011 and Martin and Bridgmon, 2012).

Table (1): Simulation boundary conditions of studied variables for different scenarios.

\begin{tabular}{ccccccccc}
\hline & \multicolumn{7}{c}{ Variable } \\
\cline { 2 - 9 } Scenario & $\begin{array}{c}\text { Span } \\
\text { length, } \\
\text { m }\end{array}$ & $\begin{array}{c}\text { Equivalent } \\
\text { output } \\
\text { length, }\end{array}$ & $\begin{array}{c}\text { No. of } \\
\text { Sprinklers }\end{array}$ & $\begin{array}{c}\text { Distance } \\
\text { between } \\
\text { sprinklers, } \\
\mathbf{m}\end{array}$ & $\begin{array}{c}\text { Flow } \\
\text { rate, } \\
\mathbf{m}^{3} / \mathbf{h}\end{array}$ & Soil & Crop & $\begin{array}{c}\text { ET } \\
\text { mm/day }\end{array}$ \\
\hline Scenario.1 & 30 & 56.3 & 7 & 7.5 & 7 & Sand & Alfalfa & 8 \\
Scenario.2 & 30 & 57.5 & 11 & 5 & 6.2 & Sand & Alfalfa & 8 \\
Scenario.3 & 30 & 56.3 & 18 & 2.5 & 5.5 & Sand & Alfalfa & 8 \\
Scenario.4 & 40 & 55 & 6 & 10 & 6.3 & Sand & Alfalfa & 8 \\
Scenario.5 & 40 & 56.7 & 8 & 6.67 & 6.2 & Sand & Alfalfa & 8 \\
Scenario.6 & 40 & 55 & 14 & 3.33 & 5.4 & Sand & Alfalfa & 8 \\
Scenario.7 & 50 & 56.3 & 5 & 12.5 & 6.8 & Sand & Alfalfa & 8 \\
Scenario.8 & 50 & 54.2 & 7 & 8.33 & 5.94 & Sand & Alfalfa & 8 \\
Scenario.9 & 50 & 56.3 & 12 & 4.17 & 5.8 & Sand & Alfalfa & 8 \\
\hline
\end{tabular}

\section{RESULTS AND DISCUSSION}

\section{Model Calibration and robustness}

In this study, a two-step approach is followed for model calibration and robustness: first, validation experiments on the micro level, where typical model variables are compared to the real world data; and second, comparing manufactured (catalogue) data with simulated data in order to test the model's aggregate representation. 
Figure (2) shows the Mean nozzle flow rate for different simulated scenarios and observed data. Means of nozzle flow rate do not differ significantly across scenarios and observed data at the $\mathrm{p}<0.05$ level (sig. 0.211). By comparing these scenarios according to conformity of different scenarios and observed data, we found that the highest rate of convergence was in scenarios 2, 3, 6, and 9. With a deeper analysis of this comparison, there is a notable declination of the mean of nozzle flow rate in scenarios 3 and 6 by 36.17\%, 17.02\%, respectively, while the mean of nozzle flow rate has a slight increasing in scenarios 2 and 9 by $19.15 \%, 4.26 \%$, respectively. On the contrary, there is a diverging the mean of nozzle flow rate in scenarios 5 and 8 by a large margin of $65.96 \%, 80.85 \%$, respectively. Scenarios 1, 4, and 7 have abnormal results from the mean of nozzle flow rate that are increasing by more than $90 \%$.

Figure (3) shows the mean application rate for different scenarios and manufactured data. It is noted the absence of any significant difference between means of the scenarios and manufactured data at the $p<0.05$ level (sig. 0.905). On the other hand, we found that the highest rate of convergence between simulated and manufactured data was in scenarios 4, 7, and 8 with an increasing percentage of 5.83\%, 7.50\%, and 4.17 respectively, then scenarios 1,2 , and 5 by $22.64 \%, 21.53 \%$, and 20.83 respectively. Whereas, the farthest mean of water application rate was in scenario 3 by $34.44 \%$.

Unlike the nozzle flow rate and application flow rate, there is a significant difference between means of throw diameter of the scenarios and manufactured data at the $\mathrm{p}<0.05$ level (sig. 0.012). Figure (4) shows the mean throw diameter for different scenarios and manufactured data. Therefore, the post-hoc comparison was applied using the multiple comparisons (Tamhane test) to test the difference between each pair of means. Results of Tamhane test indicate that the mean of scenarios 2, 3, 6 , and 9 were significantly different with the manufactured data. However, scenarios $1,4,5,7$, and 8 did not significantly differ from the manufactured throw diameter. 


\section{The goodness CPIM model}

The goal of the goodness was to maintain the low values of errors and high values of the determination coefficient $\left(\mathrm{R}^{2}\right)$, while producing accurate predictions of the model variables. The goodness of fit of a simulation model describes how well it fits a set of observations. Measures of goodness of fit typically summarize the discrepancy between observed values and the values expected under the model in question. Figures (5), (6), and (7) show the observed/manufactured versus simulated of nozzle flow rate $\left(\mathrm{m}^{3} / \mathrm{h}\right)$, application rate $(\mathrm{mm} / \mathrm{h})$, and throw diameter $(\mathrm{m})$ for three center pivot span lengths $(30,40$ and $50 \mathrm{~m})$. Similarly, a regression analysis is done in order to estimate the relationship between the independent variable (observed/manufactured) and the dependent variable (simulated). $\mathrm{R}^{2}$ is the proportion of the total variation in predicted values that can be accounted by the relationship with measured or manufactured values. $\mathrm{R}^{2}$ values near to 1 indicate that the data points fall in a well-defined equation.

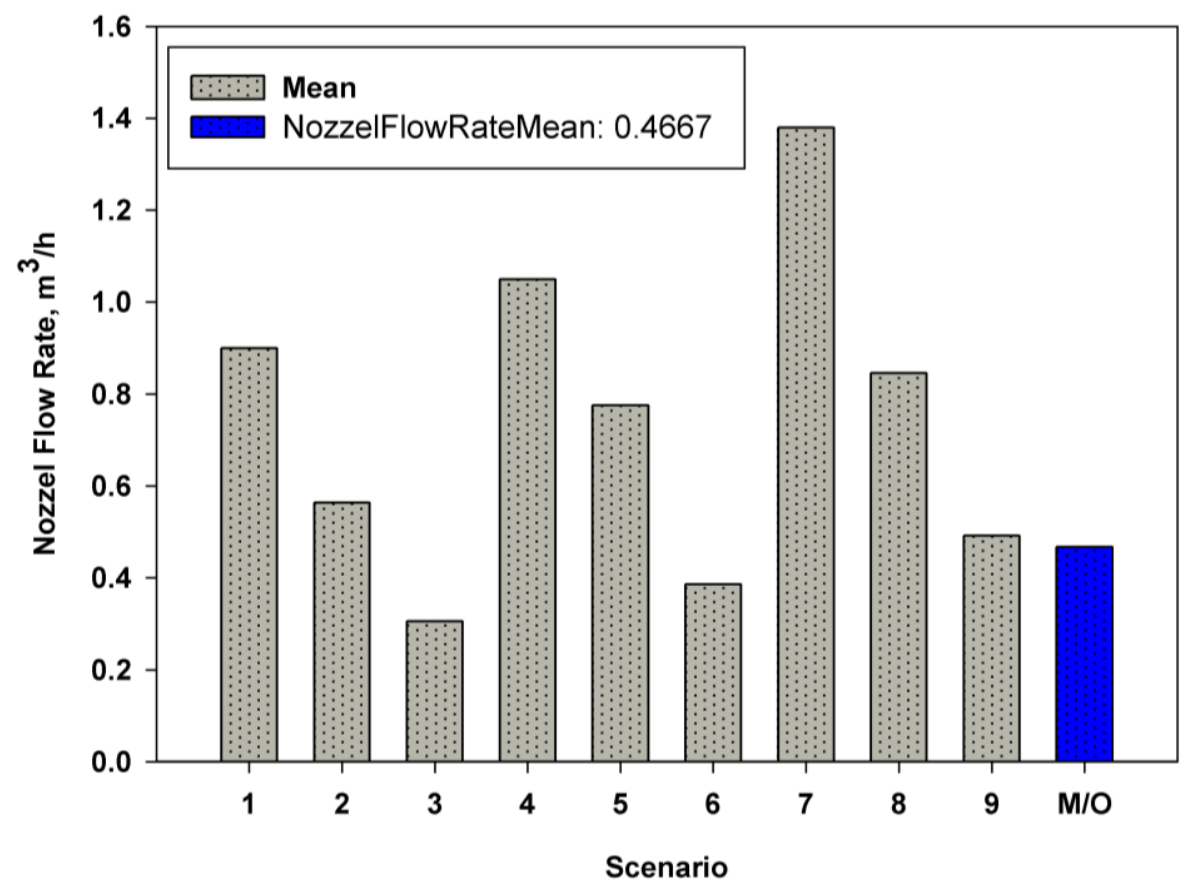

Fig. (2): Mean nozzle flow rate for different simulated scenarios and observed data. 


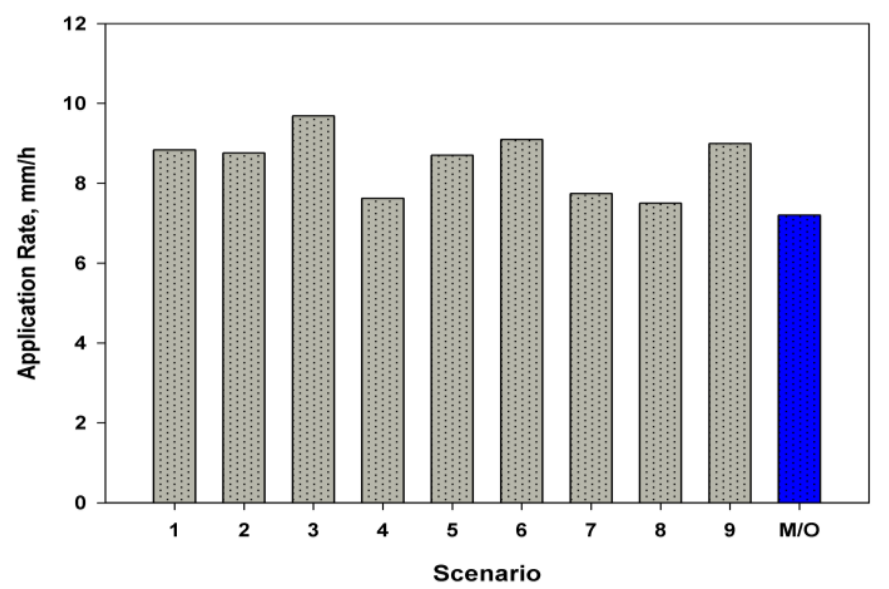

Fig. (3): Mean application rate for different scenarios and manufactured data.

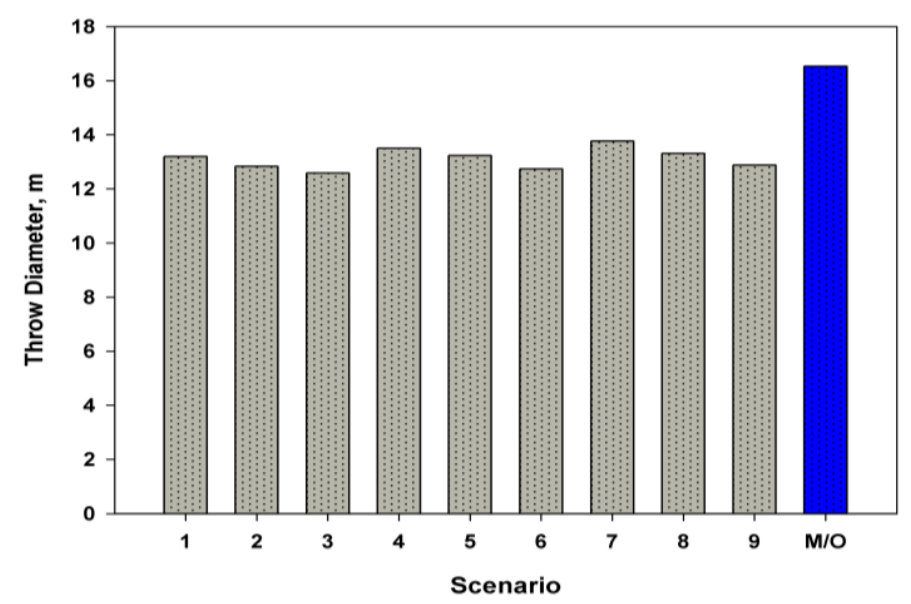

Fig. (4): Mean throw diameter for different scenarios and manufactured data.

Results obtained from the regression analysis with $\mathrm{R}^{2}$ are indicated in Table (2). According to these results, there are three groups of models that could explain the relationship between the observed/manufactured data and simulated data. Firstly, exponential models that interpret the relationship between the observed and simulated for nozzle flow rate $\left(\mathrm{m}^{3} / \mathrm{h}\right)$. The best model that explains the relationship between observed and simulated for nozzle flow rate $\left(\mathrm{m}^{3} / \mathrm{h}\right)$ among scenarios was obtained from the scenario no. 5 with $\mathrm{R}^{2}=0.967$. Secondly, linear models that interpret the relationship between manufactured and simulated 
application rate $(\mathrm{mm} / \mathrm{h})$ with a very high $\mathrm{R}^{2}$ (more than 0.99 ) for all scenarios. Finally, power models that interpret the relationship between manufactured and simulated throw diameter $(\mathrm{m})$. The best model that could explain the relationship between manufactured and simulated for throw diameter $(\mathrm{m})$ among scenarios was obtained from the scenario no. 1 with $\mathrm{R}^{2}=0.942$.
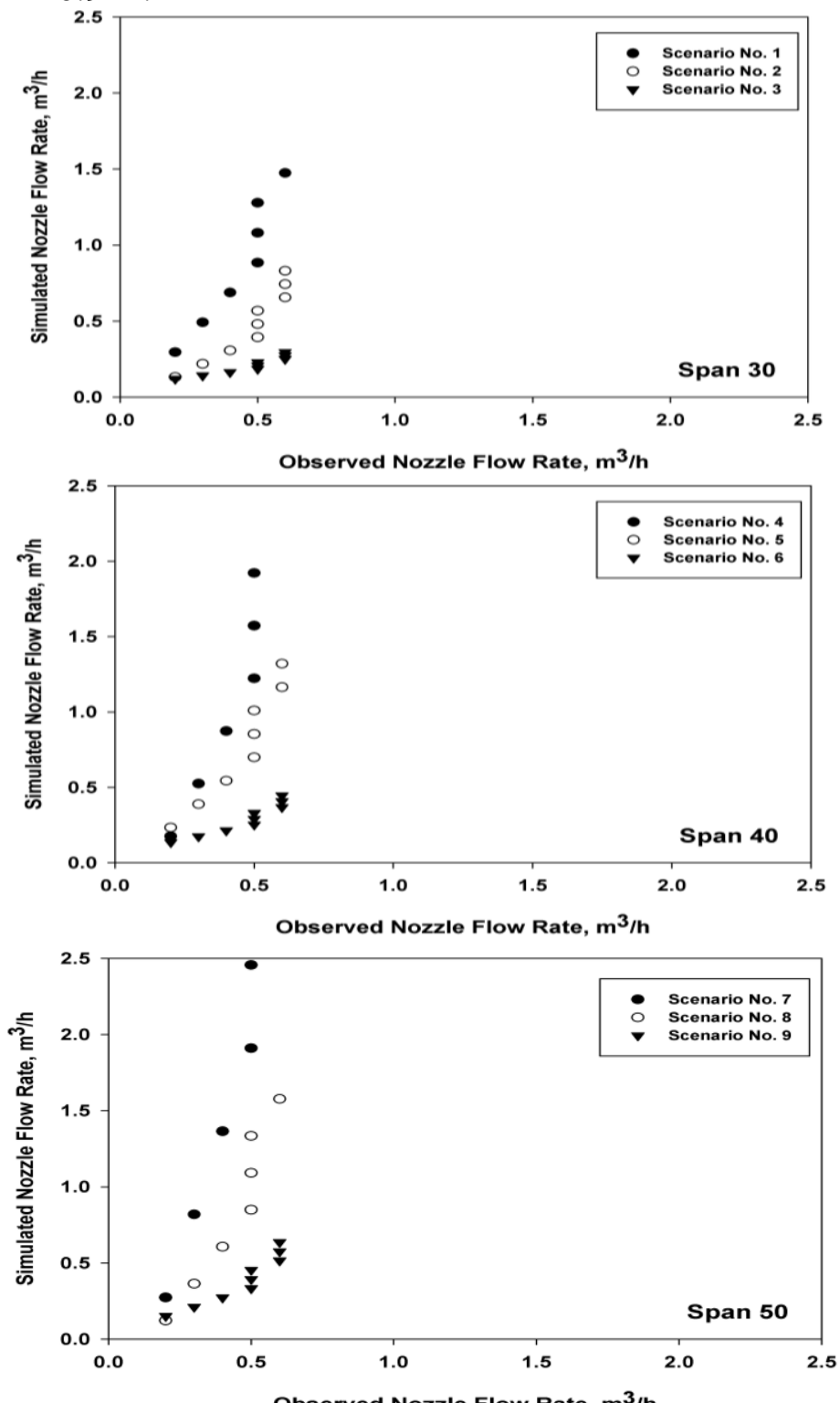

Fig. (5): Observed vs. simulated nozzle flow rate for three center pivot span lengths (30, 40 and $50 \mathrm{~m}$ ). 

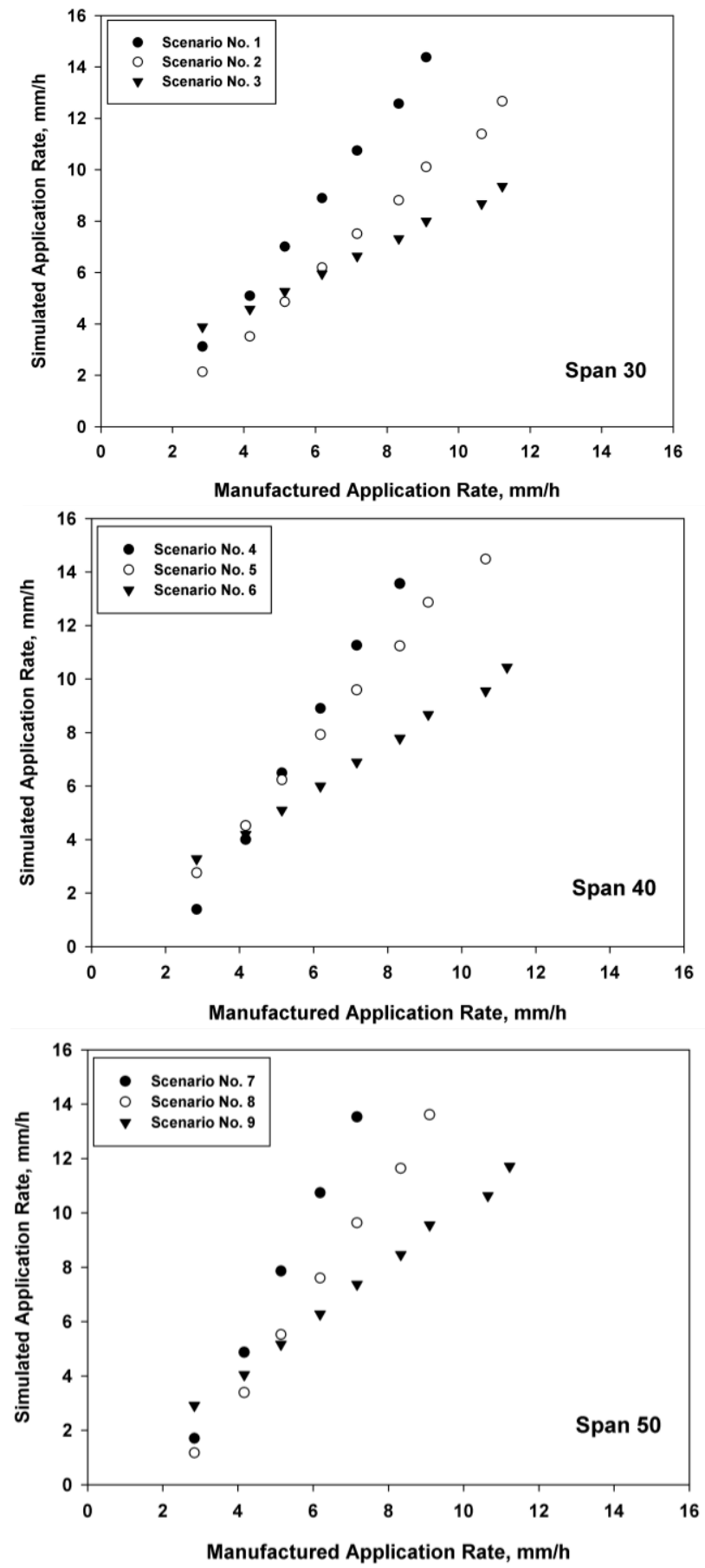

Fig. (6): Manufactured vs. simulated application rate for three center pivot span lengths (30, 40 and $50 \mathrm{~m})$. 


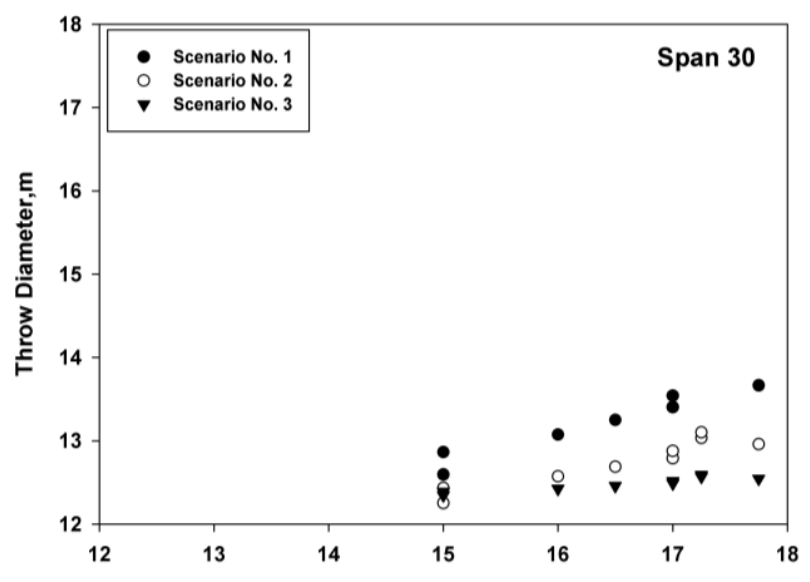

Manufactured Throw Diameter,m

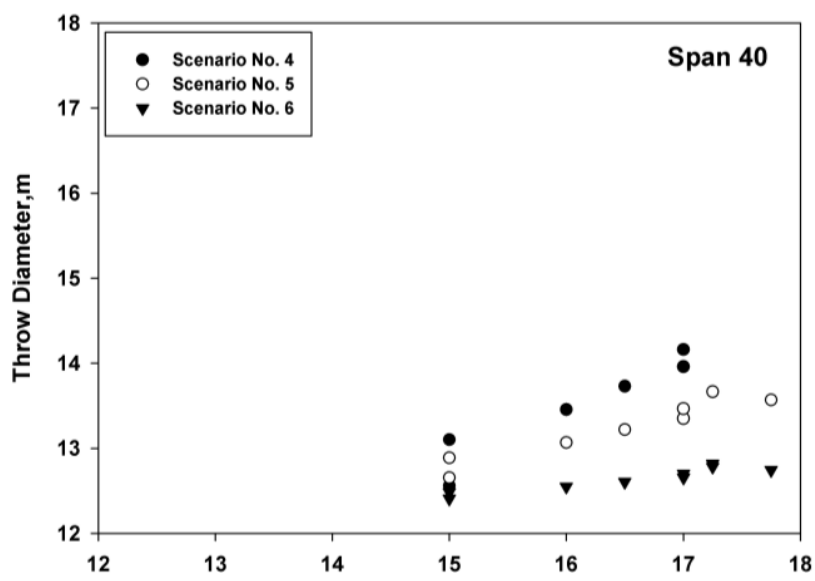

Manufactured Throw Diameter,m

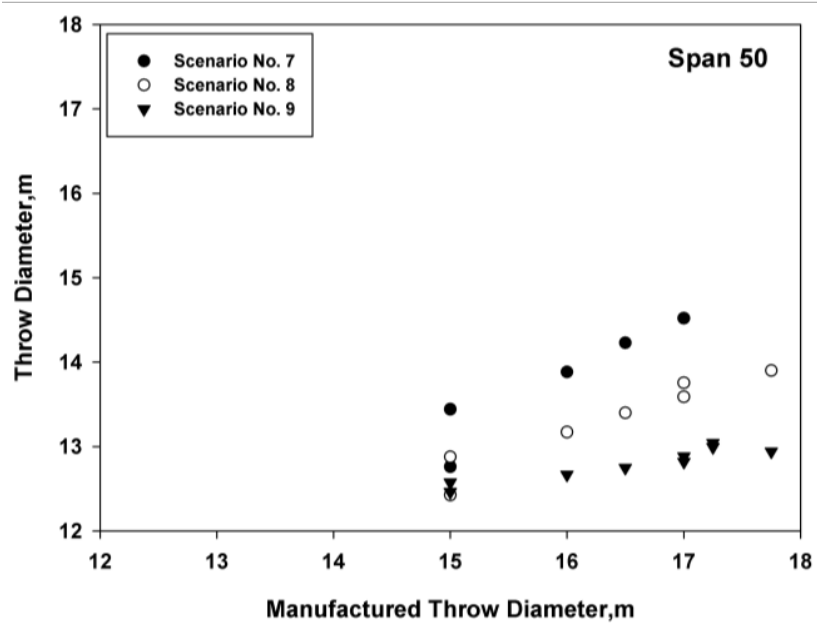

Fig. (7): Manufactured vs. simulated throw diameter for three center pivot span lengths (30, 40 and $50 \mathrm{~m}$ ). 
Table (2): Regression analysis results of observed/manufactured and simulated for nozzle flow rate $\left(\mathrm{m}^{3} / \mathrm{h}\right)$, application rate $(\mathrm{mm} / \mathrm{h})$ and throw diameter $(\mathrm{m})$.

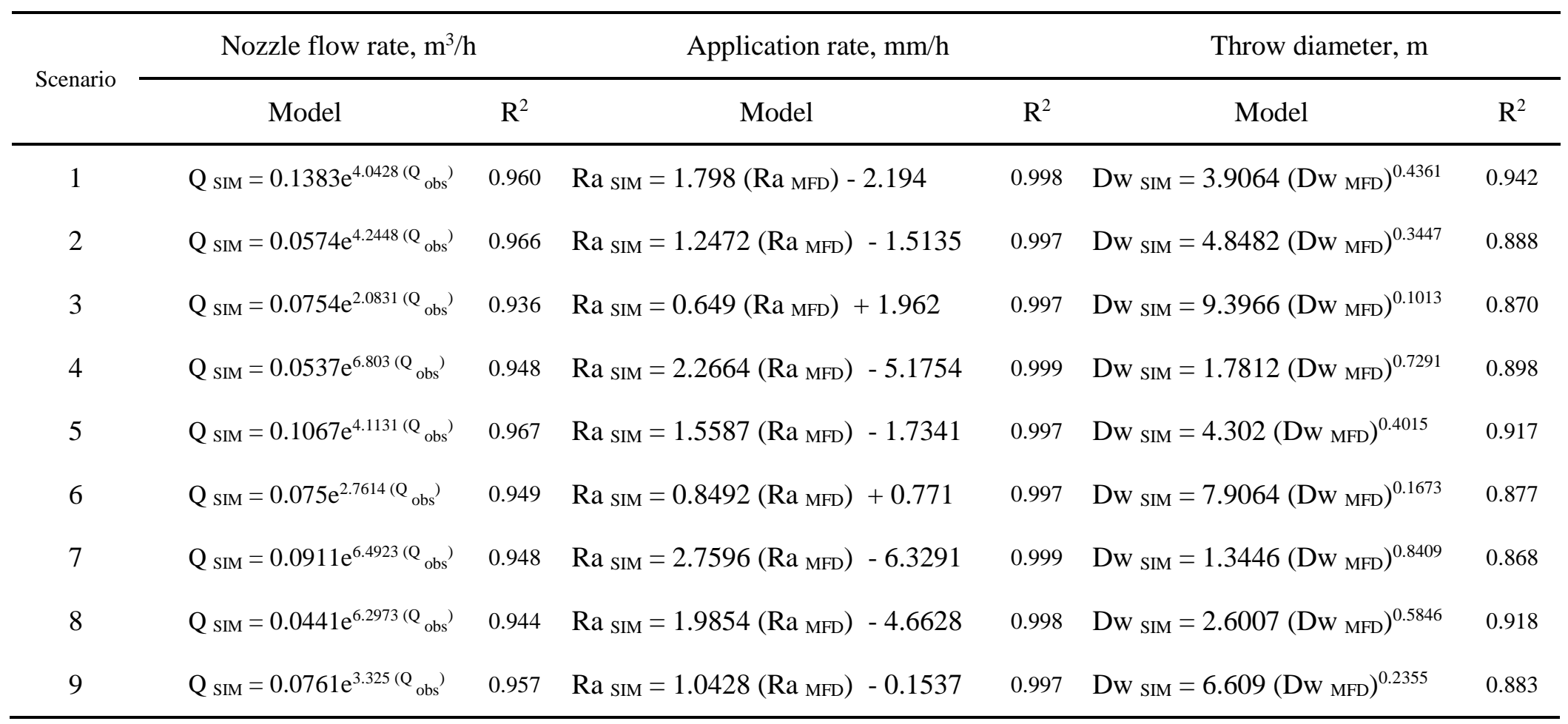




\section{CONCLUSION}

Comparisons between experimental observations/manufactured data and model simulations revealed that the model could accurately predict: (1) Water volume needed to the center pivot device based on crop type, soil type, and climatic conditions; (2) Water volume distribution along the center pivot radial line; (3) Friction loss in the center pivot machine; (4) Water application rate and nozzle flow rate along the center pivot radial line and (5) Throw diameter for each nozzle at any certain point on the center pivot. Differences in model accuracy owing to different variables affecting design and management of the center pivot were not significant. The simulation model accuracy was very high and perfectly mimic the real world for nozzle flow rate and application rate, whereas, the accuracy of the model was good for the throw diameter.

The best models that correlate the relation between the observed/manufactured and simulated results as follows:

1- Nozzle flow rate $\left(\mathrm{m}^{3} / \mathrm{h}\right)$ was in scenario 5 with $\mathrm{R}^{2}=0.967$ and explained by an exponential model: $\mathrm{Q}$ sIM $=0.1067 \mathrm{e}^{4.1131\left(\mathrm{Q}_{\mathrm{obs}}\right)}$.

2- Application rate $\left(\mathrm{m}^{3} / \mathrm{h}\right)$ was in all scenarios with a very high $R^{2}$ and explained by a linear model.

3- Throw diameter (m) was in scenario 1 with $\mathrm{R}^{2}=0.942$ and explained by a power model: Dw SIM $=3.9064\left(\mathrm{Dw}_{\mathrm{MFD}}\right)^{0.4361}$.

The CPIM simulation model accuracy was very high and perfectly mimic the real world for nozzle flow rate and application rate, whereas, the accuracy of the model was good for the throw diameter. Therefore, results of model evaluation confirm the accuracy and robustness of CPIM for simulation of center pivot variables under real field conditions. Finally, we recommend using the model as a kernel and useful tool for center pivot irrigation management and design that could be subjected for further development to provide a good tool for center pivot design and management.

\section{REFERENCES}

Al Ghobari, H. M. (2004). Sprinkler Irrigation systems. Textbook, College of Food and Agricultural Sciences, King Saud University, Saudi Arabia (Arabic). 
Bittinger, M. W. and R. A. Longenbaugh (1962). Theoretical distribution of water from a moving irrigation sprinkler. Trans. Amer. Soc. Agric. Eng. 5(1): 26-30.

Bremond, B., and B. Molle (1995). Characterization of rainfall under center-pivot: influence of measuring procedure. Journal of Irrigation and Drainage Engineering: ASCE, 121(5): 347-353.

Cape, J. (1998). Using software to review sprinkler performance. Irrigation Australia, 13(3): 18-20.

Carrion, P., J. M. Tarjuelo and J. Montero (2001). SIRIAS: A simulation model for sprinkler irrigation 1, Description of the model. Irrigation Science, 20(2): 73-84.

Faci, J. M., R. Salvador, E. Playán and H. Sourell (2001). "Comparison of fixed and rotating spray plate sprinklers". Journal of Irrigation and Drainage Engineering: ASCE, 127(4):224-233.

Heermann, D. F. and K. Stahl (2004). Center pivot evaluation and design package (CPED) - Users' manual. Ft. Collins, CO, USA: USDA-ARS-NPA-WMU.

Heermann, D. F. and P. R. Hein (1968). Performance characteristics of self-propelled center pivot sprinkler irrigation system. Transactions of the ASAE, 11(1): 11-15.

Keller, J. and R. D. Blienser (1990). Sprinkler and Trickle Irrigation. Van Nostrand Reinhold. New York. Pp. 99-115.

Merkley, G. P. and R. G. Allen (2007). Sprinkler and Trickle Irrigation. Lecture Notes, Utah State Univ., Logan, UT. Biological and Irrigation Engineering Department.

Montero, J., J. M. Tarjuelo and P. Carrion (2001). SIRIAS: A simulation model for sprinkler irrigation 2, Calibration and validation of the model. Irrigation Science, 20(2): 85-98.

Smith, R. J., M. H. Gillies, G. Newell and J. P. Foley (2008). A decision support model for travelling gun irrigation machines. Biosystems Engineering, 100(1): 126-136. 
Razali, N. M. and Y. B. Wah (2011). Power comparisions of ShapiroWilk, Kolmogorov-Smirnov, Lilliefors and Anderson-Darling tests. Journal of Statistical Modeling and analytics, 2(1), 21-33.

Doane, D. P. and L. E. Seward (2011). Measuring Skewness Journal of Statistics Education, 19(2): 1-18.

Martin, W. E. and K. D. Bridgmon (2012). Quantitative and Statistical Research Methods: From Hypothesis to Results. John Wiley and Sons, Somerset, NJ, US.

Summers, C. G. and D. H. Putnam (2008). Irrigated Alfalfa Management for Mediterranean and Desert Zones, University of California, Agriculture and Natural Resources.

Chung, C. A., 2003. Simulation Modeling Handbook: A Practical Approach, Taylor \& Francis.

Evans, R. G., S. Han, L. G. James and M. W. Kroeger (1993). CPIMA computer simulation program for center pivot irrigation systems. ASAE Paper No. 93-3065. St. Joseph, MI, USA: ASAE.

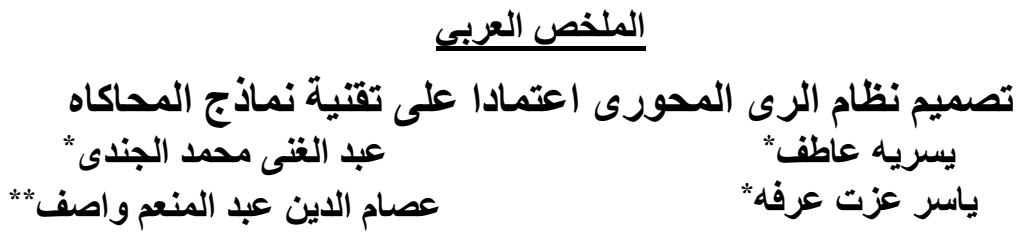

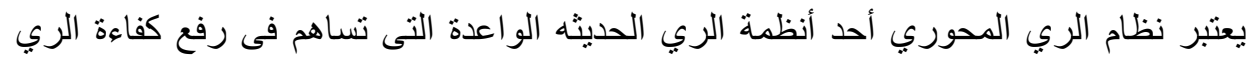

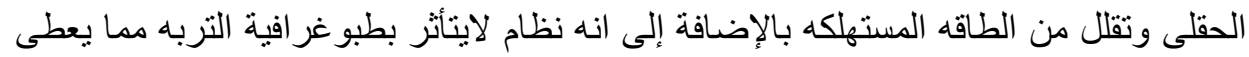

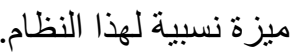

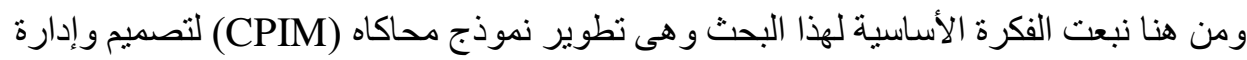

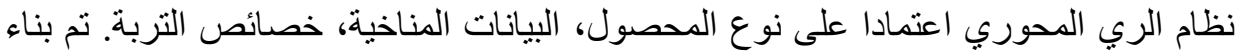
هذا النموذج باستخدام لغة البرمجة C\# بالإضافة إلى استخدام برنامج Excel في عمل جداول

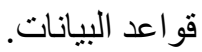

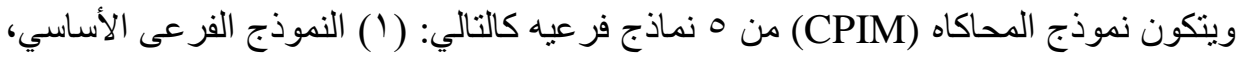

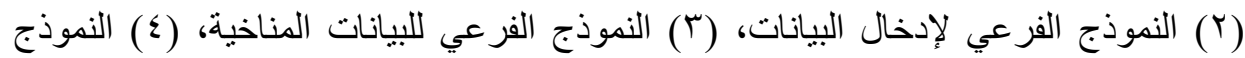

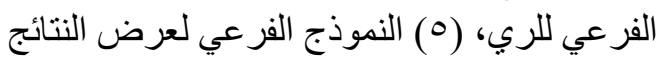
* * معهد بحوث الهندسة الزراعية. * قسم الهندسة الزراعية ـ كلية الزراعة ـ ـ جامعة عين شمس. 
ولمعرفة مدى جودة النموذج تم مقارنة 9 سيناريو هات لأهم مخرجاته بالبيانات الواقعيه حيث

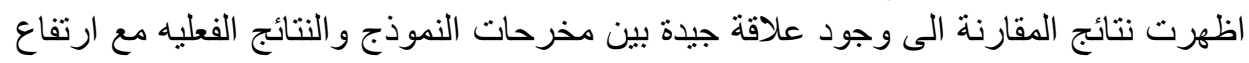

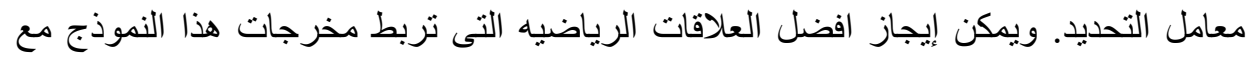

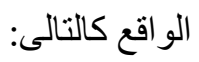

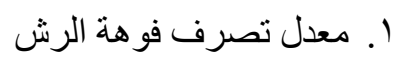

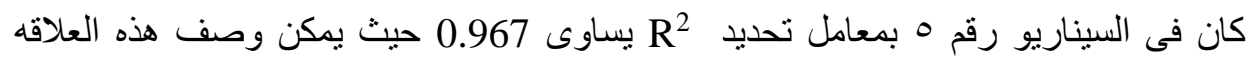
Exponential model بنموذج فين $\mathrm{Q}_{\mathrm{SIM}}=0.1067 \mathrm{e}^{4.1131\left(\mathrm{Q}_{\mathrm{obs}}\right)}$

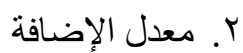
كان جيد لجميع السيناريوهات بقيم مرتفعه لمعامل التحديد R وتم توصيف هذه العلاقة بنموذج Linear model r. قطر الرش للفوهة كان فى السيناريو رقم ا بمعامل تحديد R² يساوى 0.942 حيث يمكن وصف هذه العلاقه بنموذج Power model $\mathrm{DW}_{\mathrm{SIM}}=3.9064\left(\mathrm{DW}_{\mathrm{MFD}}\right)^{0.4361}$ 